\section{Wild bank voles (Clethrionomys glariolus) are possibly a natural reservoir of campylobacters (microaerophilic vibrios)}

STRAINs of Campylobacter, a genus of microaerophilic bacteria, have been isolated by various workers from the gut and faeces of several animal species including man ${ }^{1}$, but as far as we know, there have been no reports of their isolation from rodents. The continuing importance of diseases of farm animals involving campylobacters, for example infectious infertility and sporadic abortion in cattle $^{2}$, abortion in sheep ${ }^{2}$ and dysentery in pigs $^{3}$, and the paucity of information on the source of outbreaks of some of these diseases prompted us to investigate whether campylobacters were present in the faeces of bank voles (Clethrionomys glariolus), short tailed field voles (Microtus agrestis) and long tailed field mice (Apodemus sylvaticus) from their natural habitat. These species are common throughout mainland Great Britain ${ }^{4}$ and were being trapped as part of an investigation into the distribution of pathogenic bacteria and viruses in small wild rodents. Bank voles and field mice are commonly found in woodland and scrub, and short tailed field voles are found in grassland, therefore all three species might provide a source of infection for domestic animals. We report here that bank voles carry campylobacters.

At intervals of 6 weeks during a period of 3 months bank voles and field mice were trapped in an area of mixed broadleaved woodland in Berkshire, and short tailed field voles were trapped in an area of well established grassland in Hampshire. The animals were caught in Longworth traps ${ }^{5}$ arranged in a squared grid of $3,600 \mathrm{~m}^{2}$ in each trapping area. Two traps were placed at each point, with an interstation distance of $10 \mathrm{~m}$. A faccal pellet voided by each animal was placed in $5 \mathrm{ml}$ of quarter strength Ringer's solution in a 0.5 -ounce $\mathrm{McCa}$ for not more than $3 \mathrm{~h}$ before selective culture for campylobacters on blood agar by a filtration method'. Isolation plates were examined after incubation in $30 \%(\mathrm{v} / \mathrm{v}) \mathrm{CO}_{2}$ in air for $4 \mathrm{~d}$ at $37^{\circ} \mathrm{C}$. If colonies of Campylobacter were not detected, the plates were reincubated and examined after a further $10 \mathrm{~d}$.

We isolated bacteria which we identified as Campylobacter from the faeces of 10 out of 13 bank voles, but not from the faeces of any of 12 field mice or any of 17 short tailed field voles examined. Campylobacter isolates from bank voles were motile, Gram-negative, slender curved rods with a predominance of coccal forms in old $(5 \mathrm{~d})$ cultures. On blood agar after incubation for $3 \mathrm{~d}$ at $37^{\circ} \mathrm{C}$ colonies were irregular, tending to spread. Each colony had an entire edge and was light grey with a diameter of 2-4 mm. All isolates produced catalase and reduced nitrate to nitrite, but did not produce acid in media containing glucose, grow in nutrient gelatin or hacmolyse blood. They produced $\mathrm{H}_{2} \mathrm{~S}$ detectable by lead acetate paper only when grown in a medium with added cysteine ${ }^{6}$. Growth did not occur, or was very slow, in media containing $1 \%(\mathrm{v} / \mathrm{v})$ glycine and in media incubated either in air or in anaerobic conditions. By these criteria our isolates resemble $C$. fetus ssp. venerealis biotype intermedius ${ }^{6}$, a resemblance which is interesting since campylobacters with these characteristics have been recognised as a cause of infectious infertility in cattle ${ }^{7}$.

Our work shows that animals hitherto not considered in studies on the epidemiology of diseases of domestic animals carry campylobacters and may provide a reservoir of infection. Furthermore, it is possible that Clethrionomys glariolus might provide what is much needed for research into campylobacter infections - a laboratory model for pathogenicity studies.
This work was supported by grants from the ARC.

D. S. FERnie

T. D. Healing

Department of Microbiology,

University of Reading.

Reading RGI $5 A Q, U K$

Received July 19; accepted August 24, 1976

Morris, J. A., and Park, R. W. A.. in Isolation of Anaerobes (edit. by Shapton,

D. A., and Board, R. D.), 207-217 (Academic, London, 1971).
Lawson, J. R., in Infectious Diseases of Animals: Diseases due to Bacteria (edit. by Stableforth, A. W., and Galloway, I. A.), 745-784 (Butterworth, London, 1959)

Fernie, D. S., Griffin, R. M., and Park, R. W. A., Br.vef.J., 131, 335-338 (1975) Handbook of British Mammals (edit. by Southern, H. N.), (Blackwell, Oxford, 1964)

Chitty, D., and Kempson, D. A., Ecology, 30, 536-542 (1949)

Véron, M. and Chatelain, R., Int J syst. Bact., 23, 122-134 (1973). Berg, R. L., Jutila, J. R., and Firehammer, B. D., Am. J. vet. Res., 32, 11-22
(1971).

\section{Population density affecting adult shell size of snail Cepaea nemoralis $\mathrm{L}$.}

Thomas et al..$^{1,2}$ have questioned the ability of molluscs to limit their population size by self inhibition at high densities. They suggest that plant metabolites may have caused the reduction in growth and fecundity of the aquatic snail Biomphalaria glabrata Say ascribed to crowding in previous studies ${ }^{3,4}$. Field evidence for density-dependent regulation is limited. Yom-Tov found that the fecundity of the desert snail Trochoidea seetzeni Pfeiffer was adversely affected by population density; he considered that either self-inhibition or nutritional differences were responsible. While studying the population dynamics and energetics of the land snail Cepaea nemoralis $\mathbf{L}$., we have found evidence for density-dependent effects that cannot readily be explained by resource limitation. In samples of $C$. nemoralis collected in 1968 to study shell polymorphism (M. A. PallesClark, unpublished) a negative correlation was noticed between adult shell diameter and sample size $(r=-0.60$, $P<0.001)$. Snails were collected from chalk grassland between Beacon Hill and Round Down, West Sussex. A more detailed study carried out in the same area during the summer of 1973 confirmed this effect. The density of adult $C$. nemoralis was measured by mark-recapture at nine $20 \times 20 \mathrm{~m}$ sites, situated $100-600 \mathrm{~m}$ apart. Each site was sampled in May, June and August. As there were insufficient recaptures to use multiple recapture methods for all sites, adult population densities were estimated for the second sampling occasion using the Lincoln index.

Measurement of adult shell diameter showed a $6-9 \%$ decrease in adult size associated with an increase in density from 0.5 to 5.5 adults per $\mathrm{m}^{2}$ (Fig. 1). The pattern of population density was patchy but similar to that found in 1968. There were no simple relationships between density and geographical features, for example altitude or aspect. There were slight differences in shell colour and banding morph frequencies between the sites but these did not relate to differences in adult density or shell size.

Figure 1 also shows changes in mean shell diameter with season, reflecting a change in age structure of the adult population. Separate values of shell diameter are given for May, when the collections were mostly of old adults, surviving from previous years, and for August, when new adults (with shiny shells, periostracum intact) predominated. The August results exclude snails captured and marked in either May or June. Snails were considered adult when a lip had been formed at the mouth of the shell; after lip formation there is no further increase in shell diameter. Regression lines drawn through each set of data had significantly different slopes $(P<0.02)$, the change in slope indicating that recruitment to the low density populations increased mean adult size, whereas recruitment to the high density populations had the opposite effect. Long term 